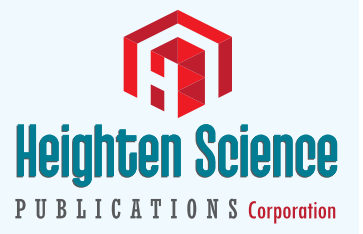

ISSN

2639-9911

\title{
Best and effective practices of wound care and healing among patients with Diabetes Mellitus
}

\author{
Jefferson Garcia Guerrero* \\ Fakeeh College for Medical Sciences, Saudi Arabia
}

\begin{abstract}
*Address for Correspondence: Jefferson Garcia Guerrero, Ph.D. NS, DNS, RN, Fakeeh College for Medical Sciences, Saudi Arabia, Tel: +966570302970; Email: jgguerrero@fcms.edu.sa; jguerrero@fakeeh.care
\end{abstract}

Submitted: 01 December 2018

Approved: 18 December 2018

Published: 19 December 2018

Copyright: ๑ 2018 Guerrero JG. This is an open access article distributed under the Creative Commons Attribution License, which permits unrestricted use, distribution, and reproduction in any medium, provided the original work is properly cited

Keywords: Systematic review; Diabetes mellitus; Wound care and practices; Wound healing

Check for updates

\section{Abstract}

Aim: With the continuing trend in the incidence of diabetic ulcer, the current researches on wound care and healing will bring best and effective practices on wound care and healing among patients suffering from diabetes mellitus.

Methods: This study utilized a systematic review of literatures in light of wound care through Pub Med database with the key words "Diabetes Mellitus," "wound practices," "wound healing," and "systematic review." The searched literatures were of case reports, interventional studies, and review papers whose main texts were in English.

Results: There were 7,988 published articles yielded from the keywords used and 16 were included in this study. The practiced management and techniques in these literatures focused on comfortable and cost efficient means of wound care and healing with the involvement of group participation than individual plan of care.

Conclusions: There are meager evidences of feasible wound and healing options that needs further studies in resolving wound issues among patients with Diabetes Mellitus. This systematic review establishes the insufficiency of high level of evidence based studies on wound healing in DM patients and brings a track for continuity of rigid studies concerning this topic.

\section{Introduction}

Wounds are commonly categorized as chronic or acute and could rise from any traumatic damage or through a collapse of an unharmed skin [1]. Healthy people have strong skin that is resistant and with a significant ability for healing but skin can be exposed to outer and inner harm brought about by older age and changed in physiology [2]. This can be intrinsic or extrinsic in nature. In people suffering from diabetes, healing of lesions is slow but progresses faster. It is therefore essential to understand diabetes and proper wound care for a better life and longevity. The incidence of diabetes is escalating faster in the countries of middle and low revenues and in 2014; a global data of $8.5 \%$ came from people aging 18 years old and above [3]. But the occurrence of diabetic foot ulcers is within $4 \%$ and $10 \%$ with $1: 4$ threat of having diabetic foot ulcer in their life [4].

Although minor injuries like burns, abrasions and lesions are normal accidents; these can bring severe medical concerns to people with diabetes [5]. Local infection can extend fast to the internal parts of the body and can be fatal. Studies suggests that curing of wounds is affected by: weakening in producing hormones related with development and therapy, decreasing in producing and repairing of new blood vessels, weakening of skin protection, and decreasing in the production of collagen [5]. There are recent studies that can help in bringing effective management of wound care among patients with diabetes. These are helpful practices that can save limbs for amputation. 
This review is an investigation on the efficacy of different practices of healthcare professionals in the conduct of wound care and healing among patients suffering from diabetes. It has unveiled comfortable management of diabetic wounds as well as hopes to patients with DM to salvage their limbs. It is with the same reason why the author conducted this review. Results stated different practices and effects and there is a solid reason for more evidence-based studies that will heighten the rate of wound healing and introduce patients with DM easy to carry out wound care and practices.

This study commenced to explore the different practices in wound care for patients with diabetes using systematic review of published evidence-based studies on wound management in diabetes.

\section{Methods}

The researcher used systematic review to unveil different practices on wound care and healing among patients with diabetes mellitus. Pub Med database was searched for illegible literatures through keywords "Diabetes Mellitus," "wound practices," "wound healing," and "systematic review." It was piloted on November 1, 2018 and focused the search on case reports, interventional studies, and review papers written in English language. The focus of the search is practices and wound care that would lead to wound healing. Yielded published articles were systematically evaluated based on the country of the author, year the article is published, site of the study, method and design of the study, management team, and the results. Prior synthesis, data is extracted via two reviewers and reviewed for accuracy by another reviewer. Inconsistencies are being identified for illegibility and consensus while recognizing ineligibles based on the criteria.

\section{Results}

With the use of keywords yielded 7,988 published articles on wound management among patients with DM but only 16 fulfilled the criteria set in this study for review. Relevant data is summarized in table 1.

\section{Country of the and year of publication}

The selected studies were authored by researchers from Finland (2), Netherlands (2), Korea (2), USA (2), Italy (1), Norway (1), Iran (1), India (1), India (1), Brazil (1), Canada (1), Turkey (1), and Taiwan (1). These are written in English and were published from 2017-2018. Therefore, the papers used for review were recent and current as these are being published in a year time.

\section{Sample}

Only four of the 16 studies are of small sample $(8,10,15,20$, and 20 cases). Most of the selected studies were of large sample $(25,30,38,40,65,100,120,130,165,167$, and 274 cases correspondingly) resulting to a mean of 105 cases (SD: 77 cases). The kinds of wounds were specified in all cases and the leading type was diabetic foot ulcer.

\section{Study design}

Five (5) studies used randomized control trials (TRCs). Others were combination of designs like: two (2) utilized retrospective study where one is a single centered while the other one is a cross-over; three (3) are prospective studies where one is randomized, blinded, multicenter, and parallel study, the second is prospective, case-cohort study, and a Pilot study, and the third is prospective, randomized, controlled, multi-center clinical study. One (1) study used 7 randomized controlled trials and 1 nonrandomized controlled trial. Others studies are: one (1) single-arm clinical trial; one (1) phase III multicenter, double-blind, randomized, placebo-controlled trial; one (1) $\mathrm{DAMO}_{2} \mathrm{CLES}$ multicenter randomized clinical trial; one (1) cluster-randomized controlled non-inferiority trial; and one (1) Non-blinded, consecutive series, randomized clinical trial. 
Table 1: Physiognomies of Selected Studies: Best and Effective Practices of Wound Care and Healing Among Diabetic Patients

\begin{tabular}{|c|c|c|c|c|c|c|}
\hline $\begin{array}{c}\text { Author; year } \\
\text { published; title of the } \\
\text { study }\end{array}$ & $\begin{array}{c}\text { Sample; } \\
\text { wound type }\end{array}$ & Study design & $\begin{array}{c}\text { Team } \\
\text { composition }\end{array}$ & $\begin{array}{l}\text { Intervention and period of } \\
\text { coverage }\end{array}$ & Primary Outcome & Major results \\
\hline Chang [6] & $\begin{array}{c}274 \\
\text { Diabetic foot }\end{array}$ & $\begin{array}{l}\text { Single-center } \\
\text { retrospective study }\end{array}$ & Surgeon & $\begin{array}{c}\text { Patient evaluation, wound } \\
\text { preparation, improving } \\
\text { vascularity, surgery and dressing, } \\
\text { and rehabilitation } \\
2005-20017\end{array}$ & $\begin{array}{l}\text { Infection and arterial } \\
\text { occlusion }\end{array}$ & Improved vascularity \\
\hline Chen et al. [7] & $\begin{array}{c}38, \\
\text { Chronic } \\
\text { diabetic foot } \\
\text { ulcer }\end{array}$ & $\begin{array}{l}\text { Randomized controlled } \\
\text { trial }\end{array}$ & $\begin{array}{l}\text { Doctor, } \\
\text { nurse }\end{array}$ & $\begin{array}{c}\text { Intervention group receives } \\
\text { standard care and HBOT while } \\
\text { control group receives standard } \\
\text { care only. } \\
20 \text { days }\end{array}$ & Wound closure & Improved wound healing \\
\hline Crews \& Candela [8] & $\begin{array}{l}25 \\
\text { Diabetic foot } \\
\text { ulcer }\end{array}$ & $\begin{array}{l}\text { Randomized controlled } \\
\text { trial }\end{array}$ & $\begin{array}{l}\text { Doctor, } \\
\text { PT }\end{array}$ & $\begin{array}{l}\text { Patients at risk for DFU's with } \\
\text { removable cast walkers in } 20 \\
\text { mins walking trials using } 5 \\
\text { footwear conditions }\end{array}$ & $\begin{array}{l}\text { Bilateral shoes brought } \\
\text { better comfort }\end{array}$ & $\begin{array}{c}\text { Ankle-high removable } \\
\text { cast walker combined } \\
\text { with contralateral limb lift } \\
\text { increases offloading and } \\
\text { improve healing }\end{array}$ \\
\hline Driver [9] & $\begin{array}{l}\text { 130, } \\
\text { Foot ulcer }\end{array}$ & $\begin{array}{l}\text { A prospective, } \\
\text { randomized, blinded, } \\
\text { multicenter, parallel } \\
\text { study }\end{array}$ & Not mentioned & $\begin{array}{l}\text { TCOT device given to intervention } \\
\text { groups following assessment } \\
\text { and standard care while the } \\
\text { control group received the sham } \\
\text { device following standard care. } \\
12 \text { weeks treatment }\end{array}$ & $\begin{array}{l}\text { Good wound results in } \\
\text { both groups }\end{array}$ & $\begin{array}{l}\text { Beneficial to older } \\
\text { population }\end{array}$ \\
\hline Eraydin \& Avsar [10] & $\begin{array}{l}65, \\
\text { Diabetic foot } \\
\text { ulcer }\end{array}$ & Randomized control trial & Nurses & $\begin{array}{l}\text { Intervention group given } \\
\text { standard wound care and foot } \\
\text { exercises for } 12 \text { weeks while } \\
\text { the control group had standard } \\
\text { wound care with no exercise } \\
12 \text { weeks }\end{array}$ & $\begin{array}{l}\text { Difference in the ulcer } \\
\text { areas in the two groups }\end{array}$ & $\begin{array}{l}\text { Significant decrease } \\
\text { of ulcer area in the } \\
\text { intervention group. }\end{array}$ \\
\hline $\begin{array}{l}\text { Health Quality } \\
\text { Ontario [11] }\end{array}$ & $\begin{array}{l}\text { 8; } \\
\text { Ulcer }\end{array}$ & $\begin{array}{c}7 \text { randomized controlled } \\
\text { trials, } 1 \text { nonrandomized } \\
\text { controlled trial }\end{array}$ & $\begin{array}{l}\text { Experts, end } \\
\text { users, and } \\
\text { applicants }\end{array}$ & $\begin{array}{l}\text { Review and assessment of } \\
\text { studies concerning efficacy } \\
\text { and cost effectiveness of HBOT } \\
\text { utilizing the standpoint of the } \\
\text { Ministry of Health and Long-Term } \\
\text { Care and assessed the clinical } \\
\text { evidence with the use of GRADE. }\end{array}$ & $\begin{array}{l}\text { Mixed results on standard } \\
\text { of care in rates of } \\
\text { amputation while there } \\
\text { is impact on standard } \\
\text { care and HBOT and no } \\
\text { difference on the adverse } \\
\text { events on both. }\end{array}$ & $\begin{array}{l}\text { Satisfaction on patients } \\
\text { using HBOT and positive } \\
\text { perceptions on healing }\end{array}$ \\
\hline Lopez-Delis [12] & $\begin{array}{l}15 \\
\text { Lower } \operatorname{limb} \\
\text { ulcer }\end{array}$ & $\begin{array}{l}\text { Randomized controlled } \\
\text { trial }\end{array}$ & $\begin{array}{l}\text { Nurses, } \\
\text { patients }\end{array}$ & $\begin{array}{l}\text { Group 1: recipients of dressing } \\
\text { system adhesive of the natural } \\
\text { latex associated with the LED } \\
\text { circuit. } \\
\text { Group 2: recipients of dressing } \\
\text { at home with calcium alginate or } \\
\text { silver foam } \\
\text { Group 3: recipients of dressing at } \\
\text { home with adhesive derived from } \\
\text { the natural latex associated with } \\
\text { the LED circuit. } \\
1 \text { month }\end{array}$ & $\begin{array}{l}\text { Significant decrease in } \\
\text { ROS formation }\end{array}$ & $\begin{array}{l}\text { Latex and phototherapy } \\
\text { brought better } \\
\text { debridement and healing } \\
\text { process }\end{array}$ \\
\hline Mathur et al. [13] & $\begin{array}{l}30, \\
\text { Grade } 1 \text { foot } \\
\text { ulcer }\end{array}$ & Randomized clinical trial & $\begin{array}{l}\text { Doctors, } \\
\text { Nurses }\end{array}$ & $\begin{array}{l}\text { Intervention group received } \\
\text { low-level laser therapy with } \\
\text { conventional therapy while } \\
\text { control group only received } \\
\text { conventional therapy } \\
6 \text { weeks }\end{array}$ & $\begin{array}{c}\text { absolute and relative } \\
\text { wound size reduction at } \\
2 \text { weeks compared to the } \\
\text { baseline parameter. }\end{array}$ & $\begin{array}{l}\text { results suggest that LLLT } \\
\text { is beneficial as an adjunct } \\
\text { to conventional therapy in } \\
\text { the treatment of diabetic } \\
\text { foot ulcers. }\end{array}$ \\
\hline $\begin{array}{c}\text { Mohammadi et al. } \\
{[14]}\end{array}$ & $\begin{array}{c}100 \\
\text { Diabetic foot } \\
\text { ulcer }\end{array}$ & A single-arm clinical trial & $\begin{array}{l}\text { Doctor, } \\
\text { nurses }\end{array}$ & $\begin{array}{l}\text { Weekly PRP treatment following } \\
\text { primary wound care }\end{array}$ & $\begin{array}{c}\text { Significant decrease of the } \\
\text { area of wound }\end{array}$ & $\begin{array}{c}\text { Platelet-rich plasma gel as } \\
\text { treatment for non-healing } \\
\text { DFU }\end{array}$ \\
\hline Park et al. [15] & $\begin{array}{c}167 \\
\text { Diabetic foot } \\
\text { ulcer }\end{array}$ & $\begin{array}{l}\text { A phase III multicenter, } \\
\text { double-blind, } \\
\text { randomized, placebo- } \\
\text { controlled trial }\end{array}$ & nurses & $\begin{array}{l}\text { Routine wound care and topical } \\
\text { or spray of saline with } 0.005 \% \\
\text { rhEGF }(n=82) \text { or }(n=85) \text { twice } \\
\text { a day } \\
12 \text { weeks }\end{array}$ & $\begin{array}{l}\text { Comparable results } \\
\text { between placebo groups } \\
\text { and the rhGF groups }\end{array}$ & $\begin{array}{c}\text { Faster healing velocity and } \\
\text { higher complete healing } \\
\text { rate regardless of HbA1c } \\
\text { levels. }\end{array}$ \\
\hline Pougatsch [16] & $\begin{array}{c}10, \\
\text { Diabetic foot } \\
\text { ulcer }\end{array}$ & $\begin{array}{c}\text { Prospective, case-cohort } \\
\text { study, } \\
\text { Pilot study }\end{array}$ & Not mentioned & $\begin{array}{c}\text { Used acceptable methods of } \\
\text { cleansing and the use of salt- } \\
\text { based spray then gauze sponges } \\
\text { soaked with the spray is used to } \\
\text { dress the ulcer and then covered } \\
\text { with dry foam or gauze and wrap } \\
\text { with ACE. }\end{array}$ & Wound closure & $\begin{array}{c}\text { Viable natural wound care } \\
\text { therapy }\end{array}$ \\
\hline
\end{tabular}




\begin{tabular}{|c|c|c|c|c|c|c|}
\hline Santema et al. [17] & $\begin{array}{l}120 \\
\text { Ischemic } \\
\text { wound }\end{array}$ & $\begin{array}{l}\mathrm{DAMO}_{2} \mathrm{CLES} \text { multicenter } \\
\text { randomized clinical trial }\end{array}$ & Not specified & $\begin{array}{l}40 \text { sessions of HBOT was } \\
\text { used for five days weekly or till } \\
\text { complete wound healing was } \\
\text { reached } \\
\text { One month }\end{array}$ & $\begin{array}{l}\text { Limb salvage and } \\
\text { wound healing }\end{array}$ & $\begin{array}{l}\text { Freedom from any } \\
\text { amputation }\end{array}$ \\
\hline $\begin{array}{c}\text { Smith-Strøm et al. } \\
{[18]}\end{array}$ & $\begin{array}{l}165 \\
\text { Diabetic foot } \\
\text { ulcer }\end{array}$ & $\begin{array}{c}\text { cluster-randomized } \\
\text { controlled noninferiority } \\
\text { trial }\end{array}$ & $\begin{array}{l}\text { Doctors, } \\
\text { Healthcare } \\
\text { personnel, } \\
\text { Community } \\
\text { nurses }\end{array}$ & $\begin{array}{c}\text { Intervention group utilized TM } \\
\text { follow-up care in the community } \\
\text { while the control group received } \\
\text { SOC. } \\
2012-2016\end{array}$ & Healing time & $\begin{array}{l}\text { Technology as relevant } \\
\text { alternative to wound care }\end{array}$ \\
\hline Volpe et al. [19] & $\begin{array}{l}20 \\
\text { Diabetic } \\
\text { wound }\end{array}$ & $\begin{array}{c}\text { Non-blinded, } \\
\text { consecutive series, } \\
\text { randomized clinical trial }\end{array}$ & $\begin{array}{l}\text { Nurses } \\
\text { Surgeons }\end{array}$ & $\begin{array}{l}\text { Group A is managed with } \\
\text { standard wound care while } \\
\text { Group B is managed with topical } \\
\text { application of CBPG consisted of } \\
\text { platelet gel application } 2 \text { times a } \\
\text { week in } 4 \text { weeks and then once a } \\
\text { week for an additional } 4 \text { weeks. } \\
\qquad 2 \text { months }\end{array}$ & Ulcer reduction & $\begin{array}{l}\text { Rapid healing than } \\
\text { standard technique }\end{array}$ \\
\hline Zelen et al. [20] & $\begin{array}{c}20 \\
\text { Diabetic foot }\end{array}$ & $\begin{array}{l}\text { A retrospective } \\
\text { crossover study }\end{array}$ & Not mentioned & $\begin{array}{l}\text { Indolent DFUs are given acellular } \\
\text { matrices } \\
12 \text { weeks }\end{array}$ & $\begin{array}{l}12 \text { out of } 20 \text { were eligible } \\
\text { for crossover treatment }\end{array}$ & Complete healing achieved \\
\hline Zelen et al. [21] & $\begin{array}{c}\text { 40, } \\
\text { Chronic } \\
\text { diabetic ulcer }\end{array}$ & $\begin{array}{l}\text { A prospective, } \\
\text { randomized, controlled, } \\
\text { multi-centre } \\
\text { clinical study }\end{array}$ & $\begin{array}{l}\text { Doctor } \\
\text { Nurse }\end{array}$ & $\begin{array}{l}\text { SOC group receives dressing } \\
\text { change daily combined with } \\
\text { collagen alginate while } \\
\text { HR-ADM group received grafts. } \\
12 \text { weeks }\end{array}$ & $\begin{array}{l}\text { Healing proportion of } \\
\text { wounds in } 6 \text { weeks. }\end{array}$ & $\begin{array}{c}\text { Clinical superiority of HR- } \\
\text { ADM and considered cost } \\
\text { effective }\end{array}$ \\
\hline
\end{tabular}

\section{Management team}

Included studies were mostly composed of nurses and doctors. One had collaboration with experts, end users, and applicants. Two of the studies did not identify the composition of the healthcare team while another two studies included surgeons.

\section{Intervention}

Selected studies utilized both intervention and control groups where the control groups are given standard wound care following evaluation and rigid assessment. Some studies incorporate exercises while other studies add follow up care. The intervention groups are also given standard wound care and additional management that includes HBOT, TCOT device, natural latex associated with the LED circuit, low-level laser therapy, PRP treatment, salt-based spray, Telemedicine follow up, cord platelet gel application, Human Reticular Acellular Dermal Matrix, and acellular reticular allogenic human dermis. The identified interventions are of usual units of weeks.

\section{Primary outcome}

Primary outcomes are of diverse occurrence like infection and arterial occlusion, wound closure, bilateral shoes bringing better comfort, good wound results in both groups, difference in the ulcer areas in the two groups, mixed results on standard of care in rates of amputation while there is impact on standard care and HBOT and no difference on the adverse events on both, significant decrease in ROS formation, absolute and relative wound size reduction at 2 weeks compared to the baseline parameter, significant decrease of the area of wound, comparable results between placebo groups and the rhGF groups, limb salvage and wound healing, faster healing time, ulcer area reduction, 12 out of 20 were eligible for crossover treatment, and healing proportion of wounds in 6 weeks. All these are suggestive of wound healing and limb improvement as to appearance and function.

\section{Discussion}

With the aim of the study to bring out evidence-based practice on wound care and healing, systematic review was undertaken. The key words "Diabetes Mellitus," "wound practices," "wound healing," and "systematic review" yielded articles focused 
on the comfort and efficiency of patients with the identified and utilized practices on wound care and healing. The researchers explored case reports, interventional studies, and review papers written in the English language. Extracted data includes name and country of the author, year the article is published, site of the study, method and design of the study, management team, and the results.

The studies were reviewed by two reviewers and the third reviewer checked and identified inconsistencies based on the set criteria. Therefore, the search was carried out systematically well. The setting of the studies selected for review is of diverse origin. Two studies came from Finland, Netherlands, Korea, and USA respectively while one study came from the countries; Italy, Norway, Iran, India, India, Brazil, Canada, Turkey, and Taiwan. These are published from 2017-2018. This means that the yielded practices are of the most recent origin and might be already in practice to most health setting to combat and improve outcomes of debilitating wounds. With the evolution of research in the medical arena today, evolution of treatment will come next. As diabetes is the medical condition, wound healing becomes a problem. Wound types among the selected literatures are of diabetic ulcer. The study consists of large sample with a mean of 105 cases (SD: 77). This suggests validity and reliability. There are 5 studies of randomized control trials while other studies mixed their designs. There are 2 retrospective studies where one is single centered while the other is a cross-over.

There are 3 prospective studies; first, a randomized, blinded, multicenter, and parallel study, the second is prospective, case-cohort study, and a Pilot study, and the third is prospective, randomized, controlled, multi-center clinical study. One of the selected study utilized 7 randomized controlled trials and 1 nonrandomized controlled trial. Other methods and designs used: single-arm clinical trial; phase III multicenter, double-blind, randomized, placebo-controlled trial; $\mathrm{DAMO}_{2} \mathrm{CLES}$ multicenter randomized clinical trial; cluster-randomized controlled non-inferiority trial; and non-blinded, consecutive series, randomized clinical trial. The dates of publication considered for inclusion are from studies published from 2017-2018. This means that the current and newest practices on wound care and healing are collated for review and these were based from the past practices that gained the reputation of healing and care. Most of the studies are published in journals.

In the study, the compositions of the teams who carried out the intervention are mostly doctors and nurses. One study collaborated with experts, end users, and applicants while two of the studies did not pinpoint the composition of the team while another two studies included surgeons. Regarding identified management, there is an intervention group and the control group where the former use additional treatment regime after the standard wound assessment and care while the later receives the conventional or traditional standard care and assessment alone.

The said intervention group received HBOT, TCOT device, natural latex associated with the LED circuit, low-level laser therapy, PRP treatment, salt-based spray, Telemedicine follow up, cord platelet gel application, Human Reticular Acellular Dermal Matrix, and acellular reticular allogenic human dermis simultaneously. This brought relative results to wound healing. It also heightened healthcare practice to a more evolved level of comfort and healing. Also, the identified regimen is of faster time treatment with the usual unit, weeks. Although the identified practices are of varieties, these are of the same results.

It brought comfort and it brought healing faster than the traditional care and assessment alone. The data suggests the same dilemma of patients in different places with regards to wound/ulcer healing. One researcher is as engaged as the other to promote skin integrity and wound healing.

And since the studies are of recent evidences and breakthroughs, wound healing is empowered to bring patients with diabetes better physicality and grip of hope against diabetic ulcer. Therefore, as per data suggests there is relative reduction of wound size. 


\section{Acknowledgment}

Engaging inspiration from those who helped in this review and the great minds in the medical research that never stop to give light on better management.

\section{References}

1. Armstrong D, Meyr A. Basic principles of wound healing. UpToDate. 2018. Ref.: https://goo.gl/crDvCb

2. Moncrieff G, Van Onselen J, Young $T$. The role of emollients in maintaining skin integrity. Wounds UK. 2015; 1: 68-74. Ref.: https://goo.gl/pUFBri

3. World Health Organization. Diabetes. 2018; Ref.: https://goo.gl/eq9jNm

4. World Union of Wound Healing Societies, Florence Congress, Position Document. Management of Biofilm. Wounds International. 2016; Ref.: https://goo.gl/VSyyqi

5. Villines Z. Diabetes and wound healing: What to know [Internet]. Medical News Today. MediLexicon International. 2018. Ref.: https://goo.gl/SELS4o

6. Chang JW, Heo W, Choi MSS, Lee JH. The appropriate management algorithm for diabetic foot: A single-center retrospective study over 12 years. Medicine (Baltimore). 2018; 97: e11454. Ref.: https://goo.gl/osJzoE

7. Chen $\mathrm{CY}, \mathrm{Wu}$ RW, Hsu MC, Hsieh CJ, Chou MC. Adjunctive Hyperbaric Oxygen Therapy for Healing of Chronic Diabetic Foot Ulcers: A Randomized Controlled Trial. J Wound Ostomy Continence Nurs. 2017; 44: 536-545. Ref.: https://goo.gl/8PUJmL

8. Crews RT, Candela J. Decreasing an offloading device's size and offsetting itsimposed limblength discrepancy lead to improved comfort and gait. Diabetes Care. 2018; 4: 1400-1405. Ref.: https://goo.gl/YuFbjt

9. Driver VR, Reyzelman A, Kawalec J, French M. A prospective, randomized, blinded, controlled trial comparingtransdermal continuous oxygen delivery to moist wound therapy for the treatment of diabetic ulcers. Ostomy Wound Manage. 2017; 63: 12-28. Ref.: https://goo.gl/tjw8fA

10. Eraydin S, Avsar G. The effect of foot exercises on wound healing in type 2 diabetic patients with a foot ulcer: A randomized control study. J Wound Ostomy Continence Nurs. 2018; 45: 123-130. Ref.: https://goo.gl/r3bcyA

11. Health Quality Ontario. Hyperbaric oxygen therapy for the treatment of diabetic foot ulcers: a health technology assessment. Ont Health Technol Assess Ser. 2017; 17: 1-142. Ref.: https://goo.gl/BXWZqG

12. Lopez-Delis A, Fleury Rosa SSR, de Souza PEN, Carneiro MLB, et al. Characterization of the cicatrization process in diabetic foot ulcers based on the production of reactive oxygen species. $J$ Diabetes Res. 2018: 4641364. Ref.: https://goo.gl/D4V5k9

13. Mathur RK, Sahu K, Saraf S, Patheja P, Khan F. et al. Low-level laser therapy as an adjunct to conventional therapy in the treatment of diabetic foot ulcers. Lasers Med Sci. 2017; 32: 275-282. Ref.: https://goo.gl/uPn1N1

14. Mohammadi MH, Molavi B, Mohammadi S, Nikbakht M, Mohammadi AM. et al. Evaluation of wound healing in diabetic foot ulcer using platelet-rich plasma gel: A single-arm clinical trial. Transfus Apher. 2017; 56: 160-164. Ref.: https://goo.gl/NMB514

15. Park KH, Han SH, Hong JP, Han SK, Lee DH, et al. Topical epidermal growth factor spray for the treatment of chronic diabetic foot ulcers: A phase III multicenter, double-blind, randomized, placebocontrolled trial. Diabetes Res Clin Prac. 2018; 142: 335-344. Ref.: https://goo.gl/hfwypG

16. Pougatsch DA, Rader A, Rogers LC. The use of a sea salt-based spray for diabetic foot ulcers: a novel concept. Wounds. 2017; 29: E5-E9. Ref.: https://goo.gl/s82eoY

17. Santema KTB, Stoekenbroek RM, Koelemay MJW, Reekers JA, van Dortmont LMC, et al. Hyperbaric oxygen therapy in the treatment of ischemic lower-extremity ulcers in patients with diabetes: results of the DAMO2CLES Multicenter Randomized Clinical Trial. Diabetes Care. 2018; 41: 112-119. Ref.: https://goo.gl/BftBgA

18. Smith-Strøm H, Igland J, Østbye T, Tell GS, Hausken MF, et al. The effect of telemedicine follow-up care on diabetes-related foot ulcers: a cluster-randomized controlled noninferiority trial. Diabetes Care. 2018; 41: 96-103. Ref.: https://goo.gl/FuPQMd

19. Volpe P, Marcuccio D, Stilo G, Alberti A, Foti G, et al. Efficacy of cord platelet gel application for enhancing diabetic foot ulcer healing after lower limb revascularization. Semin Vasc Surg. 2017; 30 106-112. Ref.: https://goo.gl/i6wUfX 
20. Zelen CM, Orgill DP, Serena TE, Galiano RD, Carter MJ, et al. Human Reticular Acellular Dermal Matrix in the Healing of Chronic Diabetic Foot Ulcerations that Failed Standard Conservative Treatment: A Retrospective Crossover Study. Wounds. 2017; 29: 39-45. Ref.: https://goo.gl/zvPQKE

21. Zelen CM, Orgill DP, Serena T, Galiano R, Carter MJ, et al. A prospective, randomised, controlled, multicentre clinical trial examining healing rates, safety and cost to closure of an acellular reticular allogenic human dermis versus standard of care in the treatment of chronic diabetic foot ulcers. Int Wound J. 2017; 14: 307-315. Ref.: https://goo.gl/i9goKg

22. Dutton $\mathrm{M}$, Chiarella $\mathrm{M}$, Curtis $\mathrm{K}$. The role of the wound care nurse: an integrative review. $\mathrm{Br} \mathrm{J}$ Community Nurs. 2014; Suppl: S39-40, S42-7. Ref.: https://goo.gl/aJifvx

23. International Best Practice Guidelines: Wound Management in Diabetic Foot Ulcers. Wounds International. 2013; Ref.: https://goo.gl/faFXPm 